\title{
To Study the Growth and Development of Yellow Melon Crop (Cucumis melo L.) under Different Growing Conditions at Different Levels of Spacing
}

\author{
A. Vidya, R. Praveenakumar*, S. Vikasa and G.K. Mukunda \\ College of Agriculture, University of Agricultural Sciences, GKVK, Bengaluru 5600065, \\ Karnataka, India \\ *Corresponding author
}

\section{A B S T R A C T}

\section{Keywords}

Yellow Melon Crop

(Cucumis melo L.),

Growth and

growing conditions

Article Info

Accepted:

24 May 2019

Available Online:

10 June 2019
Muskmelon crop flourishes well under warm climate for its cultivation and cannot tolerate frost condition, in order to grow muskmelon in irrespective of the season throughout the year and also to get a potential yield an attempt was made the performance of yellow melon var. Gladial, under different growing conditions viz., poly house and open condition at different levels of spacing. With five different treatments for the spacing levels and four replications under both the growing conditions was conducted. The parameters at ninety days after transplanting the longest vine $(372.66 \mathrm{~cm})$ in yellow melon was noticed when the plants were grown under the protected condition at $1.0 \times 0.75 \mathrm{~m}$ level of spacing. Similarly, the highest number of shoots per vine $(5.58)$, leaf area $\left(373.79 \mathrm{~cm}^{2}\right)$, number of leaves per vine (118.04), at various stages of crop growth was noticed at the same level of spacing. Under the open-field condition, longest vine $(310.33 \mathrm{~cm})$ in yellow melon at ninety days after transplanting was recorded when the plants were grown at $1.50 \times 1.50 \mathrm{~m}$ level of spacing. The plants were grown under the protected condition at $1.0 \times 0.75 \mathrm{~m}$ level of spacing took the least number of days.

\section{Introduction}

India is the second largest producer of vegetables in the world next to China. In India the vegetables are grown in an area of 10.24 million ha with an annual production of 178.92 million metric tonnes and the productivity is 17.30 tonnes per ha. India accounts for an about 13.9 per cent of the world's vegetable production (Anon., 2017). According to their commendations of ICMR, consumption of vegetables in India should be300 g per day per adult whereas, the per capita intake is only $145 \mathrm{~g}$ per day per adult. Therefore, there is a need for increasing the production of vegetables by growing high yielding genotypes or varieties or hybrids with high nutritive value and adopting improved production technologies. By the end of the year 2020, the vegetable demand in India will be around 220 million tonnes.

Muskmelon is a short duration crop, so it's gaining a lot of importance for high production potential with high nutritive value, delicacy and taste and also its suitability for 
cultivation under irrigated as well as rain fed conditions that to throughout the year. Muskmelon (Cucumis melo L.) is the most important crop grown all over the world. In India, it is extensively cultivated in fertile soil with dry and hot arid climatic conditions.

Muskmelon is highly relished because of its flavour, sweet taste and refreshing effect. It is a good source of dietary fibre, beta-carotene, folic acid, potassium, vitamins $\mathrm{C}$ and $\mathrm{A}$, muskmelon not only helps to stay healthy and is also good for skin and hair. The fruits are extremely variable in size and shape. They may be ellipsoid to globes, with or without longitudinal grooves. It is used for both salad and table purpose. The fruit flesh inside varies from white to cream-yellow, orange or green. The edible portion of muskmelon contains water $(92.80 \mathrm{~g} / 100 \mathrm{~g})$, carbohydrates $(5.40 \mathrm{~g}$ / $100 \mathrm{~g})$ and protein $(0.60 \mathrm{~g} \mathrm{/} 100 \mathrm{~g})$. The carbohydrates are essentially all sugars. Certain melons are the good source of vitamin A. The yellow and orange-fleshed muskmelons contain more than $2020 \mu \mathrm{g} 100$ $\mathrm{g}^{-1}$ of beta-carotene, a precursor of vitamin A. Cantaloupe contains $26.70 \mathrm{mg}$ and honeydew melon contains $9.70 \mathrm{mg}$ of vitamin C per 100 $\mathrm{g}$ of edible portion (Lisa and Li Tian, 2011).

In Karnataka, the crop is cultivated under the limited area with mostly local varieties which are low in productivity. However, of late several public and private hybrids are being popularised but they must be evaluated for different desirable characters like earliness, yield, quality, diseases and pests in the crops. The information about crop suitability to the whole dry zone of Karnataka is rather scanty.

\section{Materials and Methods}

The present investigation was carried out in Department of Horticulture, College of Agriculture, Gandhi Krishi Vigjnana Kendra Campus, University of Agricultural Sciences,
Bangalore during the rabi season in 2018 with the objectives to work out the performance of yellow melon (Cucumis melo L.) under different growing conditions at a different levels of spacing. The details of the material used and methods adopted during the course of investigation are outlined in this chapter.

\section{Climate}

The maximum and minimum temperature in a year ranges between $17.5^{\circ} \mathrm{C}$ and $30.4^{\circ} \mathrm{C}$ respectively under Bengaluru condition and also classified under the zone-5 among the agro-climatic zones of Karnataka has benefits of both the South-West and North-East monsoons. The major rainfall is received from the South-West monsoon between June to September months and North-Eastern monsoon between October to January months.

The annual rainfall ranges from $528 \mathrm{~mm}$ to $1374.4 \mathrm{~mm}$ with the mean of $915.8 \mathrm{~mm}$. The annual mean relative humidity of the location is 71 per cent.

\section{Experimental details}

Studies on the performance of yellow melon (Cucumis melo L.) under different growing conditions at different levels of spacing were laid out in a Randomized block design with following treatments and replications.

Crop: Yellow melon

Variety: Gladial

Season: January-2018 to April-2018

Design: Randomized Complete Block Design (RCBD)

Number of treatments: 05

Number of replications: 04 
Total experimental area: $400 \mathrm{~m}^{2}$ area $\left(200 \mathrm{~m}^{2}\right.$ - Open-field condition $200 \mathrm{~m}^{2}$ - Protected condition)

\section{Condition details}

Performance of yellow melon under different growing conditions at different levels of spacing.

Experiment 1. Protected Condition

Spacing for yellow melon under protected condition $=\mathrm{S}_{1}: 1.0 \mathrm{~m} \times 0.30 \mathrm{~m}$

$\mathrm{S}_{2}: 1.0 \mathrm{~m} \times 0.45 \mathrm{~m}$

$\mathrm{S}_{3}: 1.0 \mathrm{~m} \times 0.60 \mathrm{~m}$

$\mathrm{S}_{4}: 1.0 \mathrm{~m} \times 0.75 \mathrm{~m}$

$\mathrm{S}_{5}: 1.0 \mathrm{~m} \times 0.90 \mathrm{~m}$

Experiment 2. Open-field Condition

Spacing for yellow melon under open-field condition $=\mathrm{S}_{1}: 1.50 \mathrm{~m} \times 0.50 \mathrm{~m}$

$\mathrm{S}_{2}: 1.50 \mathrm{~m} \times 0.75 \mathrm{~m}$

$\mathrm{S}_{3}: 1.50 \mathrm{~m} \times 1.00 \mathrm{~m}$

$\mathrm{S}_{4}: 1.50 \mathrm{~m} \times 1.25 \mathrm{~m}$

$\mathrm{S}_{5}: 1.50 \mathrm{~m} \mathrm{x} 1.50 \mathrm{~m}$

Preparation of the land for an open-field condition

The area of an experimental plot was brought to a fine tilthe by repeated ploughing and harrowing. Weeds and stubbles were removed and finally, the land was levelled. Later the experimental plots were formed as per plan.

The raised beds were prepared at 25 meter length, $0.7 \mathrm{~m}$ breadth and $0.3 \mathrm{~m}$ height. The plots were provided with well decomposed farm yard manure as per the treatment and mixed thoroughly.

Furrows were made for sowing according to the recommended spacing between rows and plants.

\section{Preparation of the land for the protected condition}

For protected condition experiment, the natural ventilation was used. The soil in the required area of the inside was thoroughly pulverized. Weeds were completely removed and beds were brought to a fine tithe. Raised beds of $18 \mathrm{~m}$ length, $0.7 \mathrm{~m}$ width and $0.3 \mathrm{~m}$ height were prepared. Beds were incorporated with well decomposed farm yard manure as per the treatment and mixed thoroughly.

\section{Application of manures and fertilizers}

The recommended dose of farm yard manure (25 t/ha) was applied to the site and incorporated into the soil. Out of the recommended dose of fertilizers $\mathrm{N}: \mathrm{P}_{2} \mathrm{O}: \mathrm{K}_{2} \mathrm{O}$ (125:62:62 kg NPK/ha) 50 per cent of the nitrogen in the form of urea and full dose of phosphorus in the form of single super phosphate and potassium in the form of muriate of potash were applied as a basal dose to the plots and incorporated in the soil.

Remaining 50 per cent of nitrogenous fertilizer was applied after 30 days of sowing as a top dress.

\section{Growth parameters}

Three randomly selected vines were tagged in each treatment plot for recording growth parameters and the mean of the observations on these three vines was computed and recorded.

\section{Vine length}

The vine length was measured from the soil surface to the growing tip of the longest branch of the vine in all the three labelled vines in each treatment at fifteen days interval after transplanting to harvest and mean was calculated and expressed in centimetres. 


\section{No. of leaves}

The number of leaves per vine at fifteen days interval after transplanting to harvest was counted in each labelled plant of each treatment and the mean was calculated.

\section{No. of shoots}

The number of shoots per vine emerging directly from the base of the main stem from each of the labelled plants was recorded at 90 days after sowing (at harvest) and the mean number of shoots in each treatment was worked out.

\section{Leaf area}

The leaf area per vine was calculated by the analysis of well grown randomly selected twenty leaves from five plants of each treatment were collected and their area quantified by utilizing Bio-vis leaf area and expressed in centimetre square.

\section{Results and Discussion}

The results pertaining to the influence of different levels of spacing under open-field as well as protected conditions on vine length of yellow melon were noticed at starting from fifteenth days after transplanting to ninety days at an interval of fifteen days. It is clear from (Table 1) the increase in the age of the plant there was a significant corresponding increase in the length of the vine also.

Significant differences were observed among different levels of spacing for the vine length from fifteenth days after transplanting to ninety days at an interval of fifteen days. The length of the vine varied from 331.74 to372.66 $\mathrm{cm}$ (90DAT) under protected condition. The longest vine of $372.66 \mathrm{~cm}$ was recorded at $1.0 \times 0.75 \mathrm{~m}$ level of spacing and it was on par with $1.0 \times 0.90 \mathrm{~m}$ level of spacing $(363.41 \mathrm{~cm})$. However, the vine length was minimum $(331.74 \mathrm{~cm})$ at $1.0 \mathrm{x}$ $0.30 \mathrm{~m}$ level of spacing. Similarly, under open-field condition also, from fifteen days to ninety days after transplanting, significant differences were observed among different levels of spacing for the vine length.

The length of the vine varied from 276.05 to $310.33 \mathrm{~cm}$ (90DAT). At $1.50 \times 1.50 \mathrm{~m}$ spacing level, the longest vine was noticed $(310.33 \mathrm{~cm})$ and it was on par with $1.50 \times 1.25 \mathrm{~m}$ spacing $(302.24 \mathrm{~cm})$. However, the length of the vine was minimum (276.05 $\mathrm{cm})$ at $1.0 \times 0.30 \mathrm{~m}$ level of spacing.

On scrutinizing the data presented in (Table 1 ), it is clear that there were statistically significant variations with respect to growth parameters of yellow melon grown under open-field as well as protected conditions at different stages of crop growth. The variation in vine length may be attributed to the presence of strong apical dominance and also due to an increase in cell division and cell differentiation. This could be attributed to the positive response of yellow melon to favourable microclimate under the protected condition which may have enhanced the growth and development by better uptake of nutrients by the plants leading to increased rate of plant metabolic processes like, photosynthesis, respiration and better assimilation of carbohydrates and build-up of cells. Similar results of increased vine length have been reported by Pant et al., (2001) in cucumber, Rahman et al., (2002) in snake gourd, Ahmed et al., (2005) in bottle gourd, Raja et al., (2007) in bitter gourd, Anjanappa et al., (2012) in cucumber and Campagnol et al., (2012) in watermelon. Data pertaining to the number of leaves per vine of the yellow melon was recorded starting from the fifteenth day after transplanting to ninety days at an interval of fifteen days under protected as well as open-field conditions. 
Table.1 Influence of protected and open-field conditions on vine length in yellow melon

\begin{tabular}{|c|c|c|c|c|c|c|}
\hline \multirow{3}{*}{$\begin{array}{c}\text { Treatments } \\
\text { (Spacing levels) }\end{array}$} & \multicolumn{6}{|c|}{ Vine length $(\mathrm{cm})$} \\
\hline & \multicolumn{6}{|c|}{ Protected condition } \\
\hline & 15 DAT & 30DAT & 45DAT & 60 DAT & 75DAT & 90DAT \\
\hline$S_{1}(1.0 \times 0.30 \mathrm{~m})$ & 35.12 & 109.08 & 169.75 & 221.08 & 274.25 & 331.74 \\
\hline$S_{2}(1.0 \times 0.45 \mathrm{~m})$ & 38.00 & 122.33 & 185.66 & 236.50 & 289.66 & 345.33 \\
\hline$S_{3}(1.0 \times 0.60 \mathrm{~m})$ & 37.16 & 117.83 & 183.00 & 234.91 & 286.91 & 340.83 \\
\hline$S_{4}(1.0 \times 0.75 \mathrm{~m})$ & 44.41 & 133.00 & 203.16 & 258.08 & 309.89 & 372.66 \\
\hline$S_{5}(1.0 \times 0.90 \mathrm{~m})$ & 41.66 & 126.12 & 195.41 & 251.14 & 302.25 & 363.41 \\
\hline F test & $*$ & $*$ & $*$ & $*$ & $*$ & $*$ \\
\hline SEm \pm & 1.94 & 4.83 & 6.51 & 6.27 & 6.22 & 7.42 \\
\hline C.D. at $5 \%$ & 5.99 & 14.92 & 20.08 & 19.33 & 19.20 & 22.89 \\
\hline C.V. $(\%)$ & 9.90 & 7.95 & 6.95 & 5.21 & 4.25 & 4.23 \\
\hline \multicolumn{7}{|c|}{ Open-field condition } \\
\hline $\mathrm{S}_{1}(1.50 \times 0.50 \mathrm{~m})$ & 34.75 & 99.75 & 152.91 & 198.08 & 237.49 & 276.05 \\
\hline $\mathrm{S}_{2}(1.50 \times 0.75 \mathrm{~m})$ & 36.08 & 103.91 & 158.25 & 203.66 & 243.06 & 284.41 \\
\hline $\mathrm{S}_{3}(1.50 \times 1.00 \mathrm{~m})$ & 39.16 & 112.58 & 165.50 & 210.41 & 249.00 & 290.74 \\
\hline $\mathrm{S}_{4}(1.50 \times 1.25 \mathrm{~m})$ & 40.25 & 116.22 & 174.75 & 220.89 & 258.70 & 302.24 \\
\hline $\mathrm{S}_{5}(1.50 \times 1.50 \mathrm{~m})$ & 43.33 & 121.99 & 180.44 & 228.41 & 267.58 & 310.33 \\
\hline F test & $*$ & $*$ & $*$ & $*$ & $*$ & $*$ \\
\hline SEm \pm & 1.56 & 3.95 & 5.47 & 5.73 & 5.25 & 5.94 \\
\hline C.D. at $5 \%$ & 4.82 & 12.19 & 16.88 & 17.67 & 15.75 & 17.83 \\
\hline C.V. (\%) & 8.09 & 7.13 & 6.58 & 5.40 & 4.18 & 4.06 \\
\hline
\end{tabular}


Table.2 Variation in production of number of leaves per vine in yellow melon under the protected and open-field conditions

\begin{tabular}{|c|c|c|c|c|c|c|}
\hline \multirow{3}{*}{$\begin{array}{c}\text { Treatments } \\
\text { (Spacing levels) }\end{array}$} & \multicolumn{6}{|c|}{ Number of leaves / vine } \\
\hline & \multicolumn{6}{|c|}{ Protected condition } \\
\hline & 15 DAT & 30DAT & 45DAT & 60 DAT & 75DAT & 90DAT \\
\hline$S_{1}(1.0 \times 0.30 \mathrm{~m})$ & 15.06 & 38.91 & 59.83 & 78.66 & 90.58 & 99.25 \\
\hline$S_{2}(1.0 \times 0.45 \mathrm{~m})$ & 16.75 & 46.50 & 66.50 & 86.08 & 97.58 & 106.74 \\
\hline$S_{3}(1.0 \times 0.60 \mathrm{~m})$ & 16.16 & 45.16 & 65.33 & 84.16 & 95.91 & 104.41 \\
\hline$S_{4}(1.0 \times 0.75 \mathrm{~m})$ & 19.08 & 54.41 & 73.66 & 95.41 & 107.97 & 118.04 \\
\hline $\mathrm{S}_{5}(1.0 \times 0.90 \mathrm{~m})$ & 18.00 & 50.68 & 71.08 & 91.66 & 103.55 & 113.49 \\
\hline F test & $*$ & $*$ & $*$ & $*$ & $*$ & $*$ \\
\hline SEm \pm & 0.71 & 2.53 & 2.70 & 3.01 & 2.92 & 3.35 \\
\hline C.D. at $5 \%$ & 2.21 & 7.82 & 8.35 & 9.29 & 9.02 & 10.33 \\
\hline C.V. (\%) & 8.45 & 10.77 & 8.05 & 6.91 & 5.90 & 6.18 \\
\hline \multicolumn{7}{|c|}{ Open-field condition } \\
\hline $\mathrm{S}_{1}(1.50 \times 0.50 \mathrm{~m})$ & 13.00 & 38.08 & 56.16 & 75.74 & 88.16 & 100.16 \\
\hline$S_{2}(1.50 \times 0.75 \mathrm{~m})$ & 14.58 & 43.24 & 61.08 & 81.58 & 93.58 & 104.83 \\
\hline$S_{3}(1.50 \times 1.00 \mathrm{~m})$ & 14.91 & 45.41 & 64.66 & 85.66 & 96.46 & 107.41 \\
\hline $\mathrm{S}_{4}(1.50 \times 1.25 \mathrm{~m})$ & 16.00 & 48.74 & 68.08 & 89.66 & 100.41 & 111.33 \\
\hline $\mathrm{S}_{5}(1.50 \times 1.50 \mathrm{~m})$ & 17.08 & 52.41 & 73.50 & 94.08 & 105.49 & 115.50 \\
\hline F test & $*$ & $*$ & $*$ & $*$ & $*$ & $*$ \\
\hline SEm \pm & 0.72 & 2.42 & 2.84 & 3.25 & 3.25 & 2.60 \\
\hline C.D. at $5 \%$ & 2.23 & 7.46 & 8.78 & 10.04 & 10.03 & 8.03 \\
\hline C.V. $(\%)$ & 9.60 & 10.61 & 8.80 & 7.63 & 6.72 & 4.83 \\
\hline
\end{tabular}

Table.3 Production of number of shoots per vine and leaf area in yellow melon under the protected and open-field conditions

\begin{tabular}{|c|c|c|c|c|}
\hline \multirow{2}{*}{$\begin{array}{c}\text { Treatments } \\
\text { (Spacing levels) }\end{array}$} & \multicolumn{2}{|c|}{$\begin{array}{c}\text { Number of shoots/vine } \\
\text { Leaf area(cm }\end{array}$} \\
\cline { 2 - 5 } & $\begin{array}{c}\text { Protected } \\
\text { condition }\end{array}$ & $\begin{array}{c}\text { Open-field } \\
\text { condition }\end{array}$ & $\begin{array}{c}\text { Protected } \\
\text { condition }\end{array}$ & $\begin{array}{c}\text { Open-field } \\
\text { condition }\end{array}$ \\
\hline $\mathbf{S}_{\mathbf{1}}$ & 3.66 & 4.70 & 350.43 & 315.29 \\
\hline $\mathbf{S}_{\mathbf{2}}$ & 4.41 & 5.36 & 356.68 & 322.88 \\
\hline $\mathbf{S}_{\mathbf{3}}$ & 4.16 & 5.58 & 363.73 & 327.68 \\
\hline $\mathbf{S}_{\mathbf{4}}$ & 5.58 & 6.04 & 373.79 & 333.75 \\
\hline $\mathbf{S}_{\mathbf{5}}$ & 4.66 & 6.33 & 367.37 & 340.76 \\
\hline F test & $*$ & $*$ & $*$ & $*$ \\
\hline SEm $\mathbf{S E}$ & 0.35 & 0.30 & 4.14 & 5.36 \\
\hline C.D. at 5 \% & 1.10 & 0.92 & 12.77 & 16.53 \\
\hline C.V.(\%) & 15.86 & 10.72 & 2.28 & 3.26 \\
\hline
\end{tabular}


It is clear from (Table 2) to be that there was a significant increase in the number of leaves per vine. Significant differences were observed among different levels of spacing for the character number of leaves per vine. With respect to the spacing (90DAT), there was significantly the highest number of leaves per vine of 118.04 was observed at $1.0 \times 0.75$ $\mathrm{m}$ level of spacing and it was on par with 1.0 $\mathrm{x} 0.90 \mathrm{~m}$ (113.49). However, the least number of leaves per vine was observed at $1.0 \times 0.30$ $\mathrm{m}$ spacing under the protected condition (99.25). It shows statistically significant results. Similarly, under the open-field condition also, from fifteen days after transplanting to ninety days, significant differences were observed among different levels of spacing for the vine length. The number of leaves per vine varied from 100.16 to 115.50 (90DAT). The highest number of leaves per vine was recorded at $1.50 \times 1.50 \mathrm{~m}$ level of spacing (115.50) and it was on par with $1.50 \times 1.25 \mathrm{~m}$ (111.33). However, the minimum number of leaves per vine was noticed at $1.50 \times 0.50 \mathrm{~m}$ level of spacing (100.16).

The number of leaves per vine is another most important growth parameter which will have a direct and positive impact on yield. The number of leaf production depends upon the length of the vine also. With the increase in the vine length number of leaf production also increases more. The number of leaves per vine differed significantly as it decides the efficiency of photosynthetic activity which helps in better growth and yield of the crop. This increased vine length may be due to balanced nutrition which helped in increasing chlorophyll content in leaf and better synthesis of carbohydrate in the plants and which is utilized in the building of new cells at protected as well as open-field condition as in Table 2. The results obtained are in agreement with Ahmed et al., (2004) in cucumber, Munshi and Acharyya (2005) in bottle gourd and Anjanappa et al., (2012) in cucumber.

The impact of open-field and protected conditions on production of the number of shoots per vine in yellow melon is presented in (Table 3). There is a significant influence of growing conditions and also spacing on a production of the number of shoots per vine in yellow melon. The number of shoots per vine was significant among the varied levels of spacing and it is ranged from 3.66 to 5.58 under the protected condition. The highest number of branches per vine was recorded in $1.0 \times 0.75 \mathrm{~m}$ spacing level (5.58) and it was on par with 1.0 x $0.90 \mathrm{~m}$ (4.66). The least number of branches per vine was noticed in $1.0 \times 0.30 \mathrm{~m}$ spacing (3.66).In open-field condition, the number of shoots per vine varied from 4.70 to 6.33 . At $1.50 \times 1.50 \mathrm{~m}$ (6.33) treatment shows the highest number of shoots per vine and it was followed by $1.50 \mathrm{x}$ $1.25 \mathrm{~m}(6.04)$ and $1.50 \times 1.00 \mathrm{~m}$ (5.58) while the least number of shoots per vine was noticed in $1.50 \times 0.50 \mathrm{~m}$ (4.70). These results are also statistically significant.

A significant difference in the number of shoots per vine may be due to variation in vine length among the varied levels of spacing. In the present study, the significant positive correlation was found with the number of shoots per vine and vine length. It indicates that as the vine length increases the number of shoots was also more. Several factors could be attributed to the prevailing favourable climate under both the conditions which helped the plants in better utilization of solar radiation, nutrients and water for the synthesis of photosynthates and also prevailing higher temperature might have helped in fast multiplication of cells and cellular elongation resulting in better growth of roots and shoots which helped better vegetative growth. The results obtained are in agreement with Nagalakshmi et al., (2001) in 
sweet pepper, Gichimu et al., (2008) in watermelon and Nweke et al., (2013) in cucumber.

There was a significant variation on leaf area per vine in yellow melon under the protected as well as open-field conditions. The results pertaining to the influence of the production of leaf area per vine at the fully grown stage of the yellow melon was noticed. These results are tabulated in (Table 3). Significantly highest leaf area per vine $\left(373.79 \mathrm{~cm}^{2}\right)$ at fully grown condition was noticed in yellow melon plants when spaced at $1.0 \times 0.75 \mathrm{~m}$ and it was on par with $1.0 \mathrm{x}$ $0.90 \mathrm{~m}\left(367.37 \mathrm{~cm}^{2}\right)$ and $1.0 \mathrm{x} 0.60 \mathrm{~m}$ (363.73) under protected condition. Likewise, lowest leaf area per vine was found in $1.0 \mathrm{x}$ $0.30 \mathrm{~m}\left(350.43 \mathrm{~cm}^{2}\right)$ which was also found to be statistically significant. The values for leaf area per vine ranged from $315.29 \mathrm{~cm}^{2}$ to $340.76 \mathrm{~cm}^{2}$ with a significant difference under open-field condition. The highest leaf area was recorded in $1.50 \times 1.50 \mathrm{~m}\left(340.76 \mathrm{~cm}^{2}\right)$ and it was followed by $1.50 \times 1.25 \mathrm{~m}(333.75$ $\left.\mathrm{cm}^{2}\right)$ and $1.50 \times 1.00 \mathrm{~m}\left(327.68 \mathrm{~cm}^{2}\right)$ while $1.50 \times 0.50 \mathrm{~m}\left(315.29 \mathrm{~cm}^{2}\right)$ recorded the least leaf area.

The leaf area is associated with the length of the vine and also a number of leaves per vine. The more the vine length and the higher number of leaves, the greater will be the leaf area. The highest leaf area per vine may be attributed to the vertical training of yellow melon plants in the protected and also under open-field vines were allowed to spread. The highest growth due to congenial environmental conditions like optimum temperature, uniform and timely supply of water and optimum soil moisture level throughout the lifespan of the vine. This was in confirmation with studies conducted by Soltani et al., (1995) in watermelon, Maharana et al., (2005) in pumpkin and Mirabad et al., (2013) in cantaloupe.

\section{References}

Ahmed, M., Hamid, A. and Akbar, Z. Growth and yield performance of six cultivars of cucumber (Cucumis sativus L.) under the agro-climatic conditions of Rawalakot, Azad Jammu and Kashmir. Int. J. Agric. Bio. (2004); 6(2): 396399.

Ahmed, N., Hakeem, Z. and Afroza, B. Performance of bottle gourd genotypes under the temperate conditions of Kashmir. Haryana J. Hort. Sci., (2005); 34(3-4): 340-342.

Anjanappa, M., Venkatesha, J. and Kumara, S. B. Growth, yield and quality attributes of cucumber (cv. Hassan Local) as influenced by integrated nutrient management grown under the protected condition. Veg. Sci., (2012); 39(1): 47-50.

Anonymous, 2017, National Horticultural Board. Indian horticulture database.

Gichimu, b. M., owuor, B. O. and dida, m. M. An agronomic performance of three ostpopular commercial watermelon cultivars in Kenya as compared to one newly introduced cultivar and one local landrace grown on dystricnitisols under sub-humid tropical conditions. ARPN J. Agri. Biolog. Sci., (2008); 3(5-6):332342.

Lisa, M. L..and Li Tian. Provitamin A and vitamin $\mathrm{C}$ contents in selected California-grown cantaloupe and honeydew melons and imported melons. J. Food Composition and Analysis, (2011); 24(2): 194-201.

Maharana, T., Sahu, J., Maharana, K. and Behera, K. Productivity and quality study in different accessions of pumpkin Cv. Guamal. The Orissa J. Hort., (2005); 33 (2): 118-120

Mirabad, A., Lotfi, M. and Roozban, M, R. Impact of water deficit stress on growth, yield and sugar content of cantaloupe 
(Cucumis melo L.).Int. J. Agri. Crop Sci., (2013); 5(22): 2778-2782.

Munshi, R. and Acharyya, P. Varietal evaluation in bottle gourd genotypes. Indian Agric., (2005); 49(3\&4): 213221.

Nagalakshmi, S., Nandakumar, N., Palaniswamy, D. and Sreenarayana, V. V. Naturally ventilated polyhouse for vegetable cultivation. South Indian Hort., (2001); 49 (special): 345-346.

Nweke, I.A., Orji, E.C. and Andijearu, S.I. The effect of staking and plant spacing on the growth and yield of cucumber (Cucumis sativus L.). J. Environ. Sci, Toxicology and Food Tech., (2013); 3(4): 26-31.

Pant, T., Joshi, R.P., Bhos, A.S. and Kumar, N. Identification of suitable vegetable cropping sequence for greenhouse cultivation in Uttaranchal Hills. Veg. Sci. (2001); 28(2): 143-145.

Rahman, M. A., Hossain, M.D., Islam, M.S., Biswas, D.K. and Ahiduzzaman, M., Genetic variability, heritability and path analysis in snakegourd (Trichosanthes anguina L.). Pakistan J. Bio. Sci., (2002); 5(3):284-286.

Raja, S., Bagle, B.G. and Dhandar, D.G., Genetic variability studies in bitter gourd for zero irrigated condition of semi-arid ecosystem. Indian J. Hort., 2007; 64(4): 425-429.

Soltani, N., Anderson, L. J. and Hamson, A. R., Growth analysis of watermelon plants grown with mulches and row covers. J. Amer. Soc. Hort. Sci., (1995); 120 (6): 1001-1009.

\section{How to cite this article:}

Vidya, A., R. Praveenakumar, S. Vikasa and Mukunda, G.K. 2019. To Study the Growth and Development of Yellow Melon Crop (Cucumis melo L.) under Different Growing Conditions at Different Levels of Spacing. Int.J.Curr.Microbiol.App.Sci. 8(06): 3091-3099. doi: https://doi.org/10.20546/ijcmas.2019.806.369 